\title{
DEKONSTRUKSI REPRESENTASI PEREMPUAN PADA POSTER FILM PAHLAWAN SUPER PRODUKSI HOLLYWOOD
}

\author{
Shienny Megawati Sutanto \\ Visual Communication Design, Fakultas Industri Kreatif, Universitas Ciputra \\ shienny.megawati@ciputra.ac.id
}

\begin{abstract}
Abstrak
Dekonstruksi representasi perempuan dalam film, sebagai bentuk ekspresi sosial budaya, merupakan sebuah upaya untuk membongkar tradisi yang didominasi nilai-nilai patriaki baik yang digambarkan secara terang-terangan maupun tersamar. Tujuan dari upaya tersebut untuk memperlihatkan bagaimana hegemoni dari nilai patriarki yang selalu menempatkan perempuan pada posisi marginal, dieksploitasi, dan diobjekkan oleh laki-laki. Beberapa perilaku perempuan dalam film direpresentasikan untuk dikonstruksikan secara normatif oleh masyarakat daripada perilaku lainnya. Representasi perempuan dalam film bergenre superhero baru mengalami perbaikan sejak akhir dekade lalu. Superhero perempuan mulai ditampilkan karakternya dan direpresentasikan sebagai individu yang mandiri berkepribadian kuat, mereka memiliki impian, cita-cita dan keinginan sendiri yang tidak berhubungan dengan menjadi objek afeksi karakter laki-laki. Cerita dan penokohan dalam film terefleksikan jelas pada visualisasi karakter dan materi promosi film berupa poster.
\end{abstract}

Kata Kunci: dekonstruksi patriarki, gender, semiotik, film Hollywood, poster

\begin{abstract}
The deconstruction of the representation of women in film, as a form of socio-cultural expression, is an attempt to dismantle traditions that are dominated by patriarchal values either explicitly or disguised. The purpose of these efforts is to show the hegemony of patriarchal value that always puts women in a marginal position, exploited and objectified by men. Some women's behaviors in the film represented to construed normatively by society instead of other attitudes. Representation of woman characters in the superhero film genre started to improve since the last decade. Female superheroes begin showing character and represented as independent individuals strong personalities, have dreams, have goals, have desires of their own that are unrelated to become the object of affection of a male character. Stories and characterizations in films are cleary reflected in the visualization of the characters and promotional material in the form of posters.
\end{abstract}

Keywords: gender, Hollywood movie, patriarchy deconstruction, poster, semiotic 


\section{PENDAHULUAN}

Seks dan gender seringkali mengalami kerancuan makna. Kata 'seks' merujuk pada perbedaan kodrati antara lelaki dan perempuan yang sifatnya biologis dan tidak dapat diubah, yaitu jenis kelamin biologis yang berupa organ kelamin laki-laki dan perempuan. Sedangkan gender merupakan perbedaan peran, fungsi, dan identitas yang tidak berkaitan dengan perbedaan biologis, melainkan dibentuk secara turun temurun melalui tradisi dan kebudayaan. (Mau, 2016)

Kontruksi sosiokultural dalam gender mengakibatkan adanya perbedaan karakteristik maskulin dan feminim. Padahal gender tidak sama dengan dengan seks atau jenis kelamin laki-laki dan perempuan yang bersifat biologis (Moore, 1994). Menurut Mosse (1996) Gender adalah peranan feminin atau maskulin yang disematkan oleh masyarakat berdasarkan kebiasaan turun temurun, gender berbeda dengan jenis kelamin biologis (Dwijowijoto, 2008). Sehingga, dapat disimpulkan bahwa gender adalah label yang diberikan kepada laki-laki dan perempuan bersadarkan peranan apa yang ideal untuk mereka lakukan menurut masyarakat. Seperti misalnya, perempuan diharapkan untuk menjadi lemah lembut, cantik, emosional, dan keibuan. Sementara laki-laki harus memiliki karaker kuat, tidak emosional, rasional, dan jantan (Fakih, 2016).

Realitas masyarakat modern menunjukkan bahwa peran dan fungsi gender seperti yang dipercaya oleh masyarakat tradisional tidak selalu benar, laki-laki tidak selalu kuat dan perempuan belum tentu lemah, namun definisi dan peran gender memiliki struktur sosial yang kaku dan mengikat. Sosok laki-laki sering diidentikan dengan sifat-sifat maskulin seperti: kuat, rasional, tangguh, macho, logis, dan superior. Sementara sosok perempuan acapkali digambarkan dengan sifat-sifat feminin seperti lemah, pasif, irasional, lembut, cantik, emosional, dan inferior.

Secara fisik dan biologis harus diakui memang bahwa ada perbedaan fisiologis antara laki-laki dan perempuan, namun perbedaan tersebut tidak lantas membuat perempuan sepenuhnya menjadi sosok yang mewujudkan sikap feminin dan laki-laki sebagai perwujudan sikap maskulin. Seks dan gender adalah hal yang sangat berbeda, seks tidak mendefinisikan identitas gender seseorang. Konsep maskulinitas dan feminitas tidak lebih dari konstruk-konstruk budaya yang diwariskan secara turun temurun dalam masyarakat. (Barker, 2011).

Pada masyarakat yang masih tradisional, identitas, fungsi, dan peran gender masih banyak ditentukan oleh tradisi dan budaya turun temurun. Hal ini masih terjadi di hampir semua kelompok masyarakat dan kebudayaan, peran laki-laki dan perempuan terkonstruksi secara jelas dalam sebuah rumah tangga. Laki-laki diharapkan untuk berperan sebagai kepala rumah tangga yang kuat dan bertanggung jawab melindungi keluarganya. Sedangkan perempuan diharapkan untuk berperan sebagai ibu rumah tangga, berfungsi menjadi pelayan untuk kepala rumah tangga dan mengambil posisi sebagai figur yang lemah lembut dan perlu dilindungi. 
Konstruk-konstruk tradisional maskulinitas dan feminitas ini dapat diamati dalam berbagai aspek kehidupan masyarakat negara maju seperti Amerika. Dari aspek politik misalnya, sebagai negara yang menyatakan diri paling demokratis, Amerika justru belum pernah memiliki Presiden perempuan hingga saat ini.

Aspek sosial dan budaya juga tidak luput dari pendekatan kebudayaan patriarki. Termasuk diantaranya dalam ranah industri kreatif, salah satunya adalah industri film. Sebagai kiblat film dunia, hanya 15 persen dari industri film Amerika menampilkan bintang utama aktris perempuan. (Pasquine, 2013) Film-film yang diproduksi oleh Hollywood tidak merepresentasikan kaum perempuan dengan baik, bahkan menampilkan perempuan sebagai sosok inferior dengan segala stereotip feminin jika dibandingkan kaum pria yang digambarkan sangat maskulin. Hal ini terefleksikan dengan jelas pada media-media promosi film yang berupa poster.

Akhir-akhir ini terdapat fenomena menarik dari film Amerika, yaitu mulai bermunculannya film pahlawan super yang mengetengahkan perempuan sebagai tokoh utamanya. Pahlawan super adalah sosok manusia yang dianggap kuat dan erat kaitannya dengan segala sifat maskulinitas, sehingga munculnya fenomena tokoh pahlawan super perempuan yang membintangi filmnya sendiri membangkitkan pertanyaan apakah konstruk tradisional feminitas dan maskulinitas yang selama ini melekat pada industri film telah mengalami pergeseran.

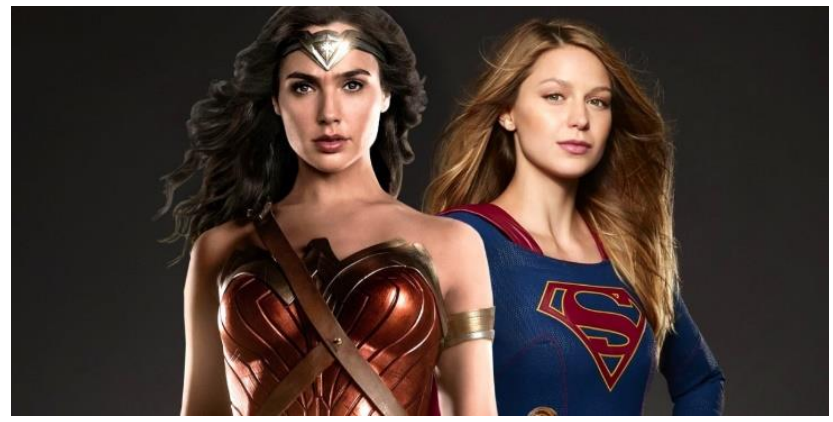

Gambar 1. Tokoh pahlawan super perempuan Wonder Woman dan Supergirl [Sumber: ScreenRant.com]

Industri komik Amerika sudah sejak lama mendapat kritik dari kaum feminis karena representasi dari superhero perempuan yang divisualisasikan hanya untuk kepentingan penonton laki-laki. Superhero perempuan biasa digambarkan dengan kostum ketat yang meneyerupai bikini dan sangat menonjolkan lekuk tubuh. Kaum feminis menilai karakter superhero perempuan hanya diperlakukan sebagai objek seks. Desain ini merupakan imbas dari industri komik yang masih terbelenggu konstruk patriakis tradisional yang menganggap bahwa karakter Superhero perempuan harus menonjolkan elemen sensual, jika ingin menarik perhatian pembaca komik yang kebanyakan adalah laki-laki. Dalam pandangan kaum feminis ini dianggap sebagai fenomena male gaze yaitu penggambaran perempuan dalam karya seni dari kacamata laki-laki maskulin heteroseksual dengan tujuan untuk menyenangkan mereka. 
Penelitian ini ingin melihat bagaimana perubahan paradigma karakter superhero perempuan dan representasinya di industri film, yang semula hanya sebagai objek seksual untuk memanjakan penonton atau penggemar komik laki-laki, kini tampil sebagai subjek. Hal ini akan diamati melalui perubahan representasi karakter perempuan dalam media promosi film khususnya poster.

\section{METODE PENELITIAN}

Metode yang digunakan untuk penelitian ini adalah metode penelitian empiris, yaitu penelitian yang didasarkan pengamatan tehadap untuk memperoleh data dan pengetahuan mendalam. Dalam penelitian ini fenomena yang akan diamati adalah representasi sosok karakter perempuan, khususnya dalam poster film pahlawan super wanita produksi Hollywood.

Poster film akan dipilih dengan metode purposive sampling, yaitu teknik non random sampling sampel dipilih berdasarkan ciri-ciri khusus yang sesuai dengan tujuan penelitian. Dalam penelitian ini poster yang akan dipilih adalah poster dari film superhero yang menampilkan tokoh wanita, yang diproduksi mulai tahun 2000 hingga 2017. Poster film yang akan dipilih adalah poster dari film superhero yang diadaptasi dari serialisasi komik Marvel Studio dan DC-comics sebagai produsen komik terbesar di Amerika.

Poster sebagai sebuah karya desain komunikasi visual terdiri dari penanda berbentuk verbal (bahasa) dan non verbal seperti visual. Oleh karena itu sebagai metode analisis untuk mengupas poster akan digunakan pendekatan semiotika yang akan menganalisa representasi ikon karakter perempuan dalam poster berdasarkan atas konsep kesetaraan gender.

\section{HASIL DAN PEMBAHASAN}

\subsection{Representasi Perempuan Dalam Film}

Peran dan representasi perempuan dalam film amat penting, khususnya dalam industri film sekelas Hollywood yang jangkauannya mendunia. Film atau sinema merupakan budaya populer, yaitu sesuatu yang tersebar luas dan mudah ditemui dimana-mana serta dipopulerkan oleh media masa (Parker, 2011). Gaya hidup masyarakat modern saat ini, khususnya yang tinggal di perkotaan sangat mudah dipengaruhi oleh budaya populer. Produk budaya populer seperti film memiliki kekuatan untuk menyampaikan ide dan pemikiran kepada penontonnya, sehingga representasi perempuan yang ditampilkan dalam film akan sangat mempengaruhi bagaimana cara pandang masyarakat terhadap perempuan (Dutt, 2014).

Peran film sebagai budaya populer sangatlah penting sebagai agen perubahan, namun sayangnya kekakuan struktur sosial yang mendefiniskan peran tiap gender ini justru kerap ditemui dalam berbagai karya film walaupun gerakan feminisme telah berusaha mengubah paradigma tersebut. 
Karakter perempuan dalam film biasanya ditampilkan sebagai obyek seksual, yang dihargai karena kecantikan fisiknya dan tidak memiliki nilai lain selain sebagai pelengkap karakter pria. Sebaliknya karakter pria digambarkan memiliki pekerjaan penting, berkuasa, dan kuat. Tidak mengherankan bahwa perempuan di representasikan sedemikian rupa dalam film Hollywood. Apa yang tersaji dalam film-film tersebut adalah akibat dari konstruk partiakis tradisional, yang masih dianut oleh sebagian besar pelaku industri sinema.

Konstruk ini menempatkan perempuan sebagai kaum lemah dan tidak perlu memiliki perkerjaan, sebaliknya pria ditempatkan dalam posisi kuat, mampu secara ekonomi, dan berkuasa. Representasi ini terefleksikan dengan jelas tidak hanya di dalam struktur cerita dan penekohan dalam film, namun juga pada poster film.

Padahal penampilan fisik dalam penokohan, peranan sosial, serta representasi tokoh perempuan dalam poster di dalam film, dapat membentuk pandangan masyarakat mengenai gender. Hal ini juga mempengaruhi persepsi anak-anak tentang ekpektasi dan peran gender pada laki-laki dan perempuan (Fischer, 2010).

Konstruk-konstruk patriakis ini yang tercermin dalam film akan mempengaruhi bagaimana masyarakat memandang seks dan gender dalam kehidupan nyata, mengakibatkan seks menjadi satu-satunya hal yang mendefinisikan peran gender seseorang dalam masyarakat.

\subsection{Film Genre Superhero}

Genre Superhero merujuk pada film-film Hollywood yang diadaptasi dari komik dan menampilkan sosok pahlawan super yang memiliki kekuatan melebihi manusia biasa. Genre film ini mulai dikenal sejak kesuksesan "Superman: The Movie" (1978). Film ini adalah film superhero pertama yang sukses secara box-office, setelah Superman genre ini terus mengalami perkembangan selama empat dekade mulai 1978 hingga 2018. Terlihat dari makin banyaknya judul dan varian film serta serial superhero yang diproduksi.

Industri film Hollywood masih sangat terpengaruh konstruk patriarkis, karena itu representasi karakter perempuan pada film superhero dapat dikatakan sangat sedikit. Dari Marvel Studio yang telah menghasilkan hampir 40 judul film sejak tahun 2000 misalnya, hanya ada tiga judul yang akan menampilkan superhero perempuan sebagai tokoh utama, yaitu "Elektra" (2005), "Captain Marvel" (2019), dan "Black Widow" (2020). Dari Jagad Sinema DC Comics atau DC-EU, tercatat dua judul film yang mengetengahkan tokoh utama superhero perempuan yaitu "Wonder Woman" (2017) dan "Wonder Woman 1984" (2020) dan serialisasi TV "Supergirl". Tokoh utama film-film superhero Marvel dan DC masih didominasi oleh karakter superhero laki-laki, dengan sejumlah superhero wanita sebagai pemeran pendukung. Sebagai akibat dari sedikitnya jumlah film superhero wanita dan masih mendominasinya karakter pria mengakibatkan kebanyakan karakter perempuan dalam film superhero direpresentasikan sebagai objek 
seksual dan sebagai korban yang harus diselamatkan oleh sang pahlawan super.(Pennell \& Behm-Morawitz, 2015).

Sebagai contohnya adalah trilogi Spiderman, franchise film superhero ini populer di awal dan pertengahan 2000-an dan disebut-sebut sebagai film superhero yang mengembalikan kepopuleran genre ini setelah hampir dua dekade. Sayangnya kebangkitan ulang genre superhero ini juga dibarengi dengan marginalisasi dan miskinnya representasi karakter perempuan di media. (Early, 2001).

Pada cerita film Spiderman 1 hingga Spiderman 3. karakter Marry-Jane Watson (MJ), yang diperankan oleh aktris Kirsten Dunst nyaris tidak memiliki kepribadian yang dikenal oleh audiens selain bahwa dia adalah love interest atau obyek cinta dari karakter Peter Parker/ Spiderman dan selalu berada dalam bahaya sehingga butuh diselamatkan oleh Spiderman. Hal tersebut terefleksikan dengan jelas pada visualisasi poster-poster film Spiderman pada Gambar 2 di bawah yang akan diamati menggunakan pendekatan Semiotika Pierce.

Menurut teori Pierce, sebuah gambar terdiri dari beberapa jenis tanda, yaitu ikon, indeks dan simbol. Ikon adalah tanda yang menyerupai dengan objek yang diwakili. Pada poster film di bawah foto Spiderman adalah ikon dari karakter Spiderman, dan foto MJ adalah ikon dari karakter MJ. Dapat diamati bahwa mulai dari poster Spiderman 1 hingga Spiderman 3, nyaris tidak terlihat ikon MJ pada poster-poster terebut. Satu-satunya ikon MJ hanya terlihat pada poster Spiderman 2, dimana ikon tersebut di tampilkan menggunakan visualisasi foto dengan pose bergelayut di dada Spiderman. Ikon MJ pada poster ini merepresentasikan figur perempuan lemah yang mengandalkan perlindungan sang superhero.
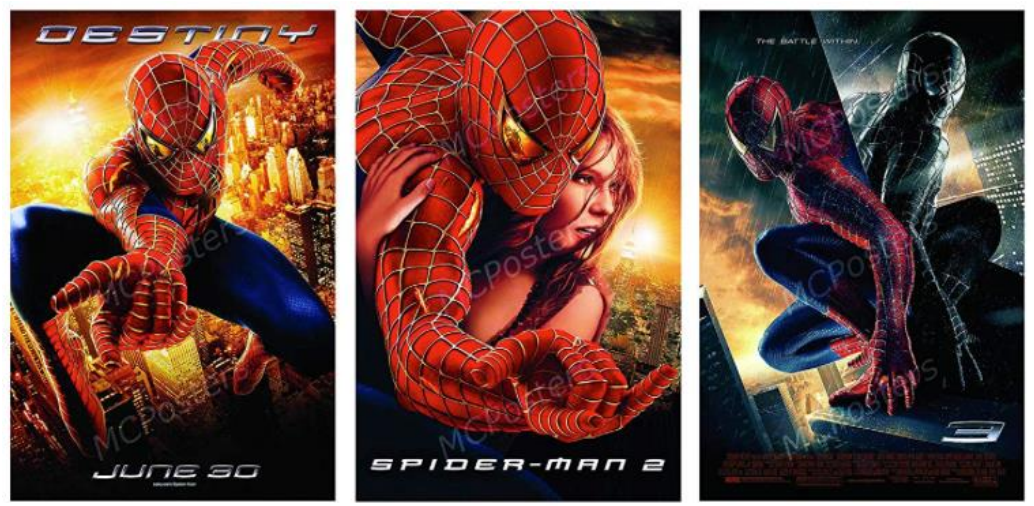

Gambar 2. Visualisasi poster Spiderman 2

[Sumber: ComicMovieMarks.com]

Buruknya representasi perempuan dalam film superhero tidak lepas dari premis utama mitos superhero, yaitu eksistensi superhero sebagai penyelamat dan penolong bagi mereka yang lemah dan tertindas. Kaum feminis di Amerika Serikat telah lama mengkritisi mitos superhero ini karena karakter-karakter yang lemah dan tertindas serta perlu diselamatkan oleh superhero adalah perempuan yang digambarkan dengan segala karakteristik feminin (Stabile, 2009). 
Superhero laki-laki adalah karakter yang mewakili ego maskulinitas audiens laki-laki di Amerika Serikat. Pandangan tradisional patriarkis barat memercayai bahwa laki-laki berperan sebagai pekerja, pelindung, dan pembangun keluarga. Perempuan sebaliknya hanya berperan menyiapkan makanan dan merawat anak. Sehingga wajar kalau pandangan inilah yang akhirnya direpresentasikan oleh media-media barat, khususnya melalui film superhero, apalagi 82\% pemegang posisi eksekutif di Hollywod adalah lakilaki. (McKay, 2013) Industri hiburan yang dikontrol oleh kaum lelaki dengan sendirinya tercermin dalam film dan serial televisi yang dihasilkan selama beberapa dekade.

Untuk mengetahui apakah telah terjadi dekonstruksi representasi perempuan pada film Supehero Hollywod, maka akan dilakukan pengamatan lebih mendalam pada beberapa poster film Superhero yang mengetengahkan karakter superhero perempuan. Yaitu Catwoman (2005), The Avengers (2012), Supergirl (2015) dan Wonder Woman (2017)

\subsection{Perempuan dalam Poster Film Superhero}

Konstruk patriarkis seperti yang tercermin dalam poster Spiderman, masih terlihat jelas pada film-film superhero sekalipun film yang menampilkan karakter superhero perempuan sebagai tokoh utamanya. Seperti misalnya film Catwoman (2004) Kritik mempermasalahkan representasi karakter perempuan dalam film ini, karena walaupun memiliki kekuatan super, tokoh Catwoman justru diceritakan mendedikasikan hidupnya untuk mendapat afeksi karakter pria. Heldman, Frankel, dan Holmes (2016) menemukan bahwa Catwoman adalah karakter pahlawan super perempuan tanpa identitas jelas dan hanya bertindak sesuai konstruk sosial patriakis hollywood.

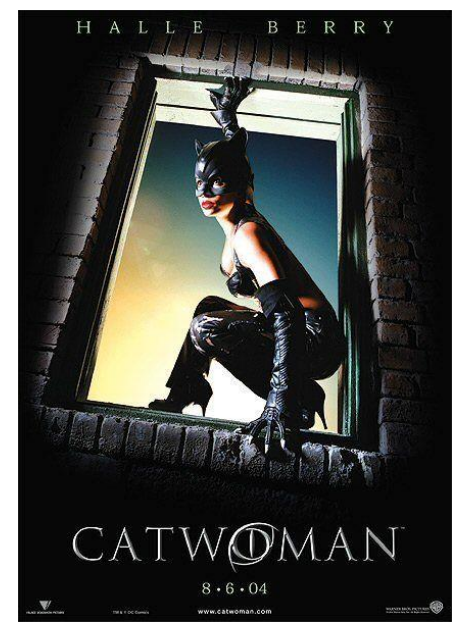

Gambar 3. Aktris Halle Bery dalam kostum Catwoman [Sumber: Di Novi et al., 2004]

Masalah lain yang sering dikritik dari film Catwoman adalah objektifikasi tubuh perempuan, khususnya sebagai obyek seksual. Visualisasi yang mengobyektifikasi tubuh Aktris Hale Berry yang memerankan Catwoman ini kerap ditemui sepanjang film. Mulai dari pemilihan kostum yang terbuat dari bahan kulit ketat dan sangat terbuka, hingga cara Catwoman berjalan sambil mengayun pinggul. Hal tersebut tercermin jelas pada visualisasi poster film Catwoman seperti terlihat pada Gambar 3 di atas. Poster tersebut memang menampilkan ikon Catwoman sebagai ikon tunggal atau tokoh utama, akan 
tetapi Catwoman tidak digambarkan seperti pahlawan yang gagah dan siap bertarung. Dalam poster ini ikon Catwoman justru direpresentasikan menggunakan foto yang pose dan kostumnya sangat menonjolkan lekuk tubuh.

Padahal visualisasi pahlawan super perempuan yang diobjektifikasi secara berlebihan dapat berakibat pada rendahnya rasa percaya diri perempuan. Oleh karena itu mulai timbul gerakan-gerakan feminisme yang berusaha mendekonstruksi nilai patriakis Hollywood dan mendorong para sineas untuk menampilkan karakter superhero perempuan yang kompeten dan tidak terbelenggu oleh peran gender tradisional. (Pennell \& Behm-Morawitz, 2015)

Representasi perempuan dalam film bergenre superhero baru mulai mengalami perbaikan sejak awal tahun 2010. Beberapa film dan serial televisi bergenre superhero mulai menampilkan karakter perempuan yang tidak mengikuti pandangan patriarkis tradisional Hollywood. Perempuan mulai direpresentasikan sebagai individu mandiri berkepribadian kuat, memiliki impian, cita-cita dan keinginan sendiri yang tidak berhubungan dengan menjadi objek afeksi karakter laki-laki.

Hal ini dapat diamati pada beberapa film superhero yang dirilis pada akhir tahun 2000an seperti "The Avengers" yang merupakan film dengan genre superhero sekaligus film dengan pendapatan tertinggi pada tahun 2012. The Avengers memang bukan film superhero biasa yang hanya menampilkan satu tokoh superhero utama saja, film ini menampilkan beberapa karakter superhero sekaligus sebagai tokoh utamanya. Yang menarik bahwa salah satu tokoh utamanya The Avengers adalah seorang superhero Perempuan Natasha Romanov alias Black Widow yang diperankan oleh aktris Scarlet Johansson.

Black Widow adalah satu-satunya karakter superhero perempuan dalam The Avengers, dia diceritakan memiliki kecerdasan dan keahlian dalam pertarungan tangan kosong, sepanjang film dia direpresentasikan sejajar dengan pahlawan pria lainnya yang menjadi anggota The Avengers. Akan tetapi, pada setiap adegan dimana Black Widow tampil karakter ini selalu diseksualisasi baik secara visual dan tekstual, serta acapkali digambarkan melalui tatapan laki-laki. Sehingga walaupun Natasha/Black Widow memiliki pengembangan karakter yang jelas, namun pada akhirnya yang paling diingat oleh penonton The Avengers adalah pakaian seksi yang dikenakan oleh Natasha. (Gerard, 2018)

Hal tersebut dapat diamati dalam visualisasi Natasha/Black Widow pada poster film The Avengers. Dalam poster seperti yang terlhat pada Gambar 5. terlihat ikon para Avengers (Iron Man, Hulk, Hawkeye, Captain America, Thor dan Black Widow) berada di medan pertempuran. Dari enam ikon pahlawan super ini, Black Widow diposisikan berjalan di lini belakang bersama tokoh Nick Fury yang bukan merupakan pahlawan super dan tidak menjadi fokus dari poster. 
Selain itu ikon Black Widow berpose membawa sebuah senjata, namun laras senjata itu menghadap ke bawah, sangat kontras jika dibandingkan dengan ikon karakter Iron Man (depan) yang mengacungkan senjata di telapak tangannya ke arah lawan. Selain itu dapat diamati bahwa ikon para superhero pria dalam poster ini semuanya dalam posisi siap bertarung, namun ikon Black Widow ditampilkan pose sensual dengan kostum yang sangat menonjolkan lekuk tubuh, menjadikan ikon Black Widow sebagai obyek seksual.

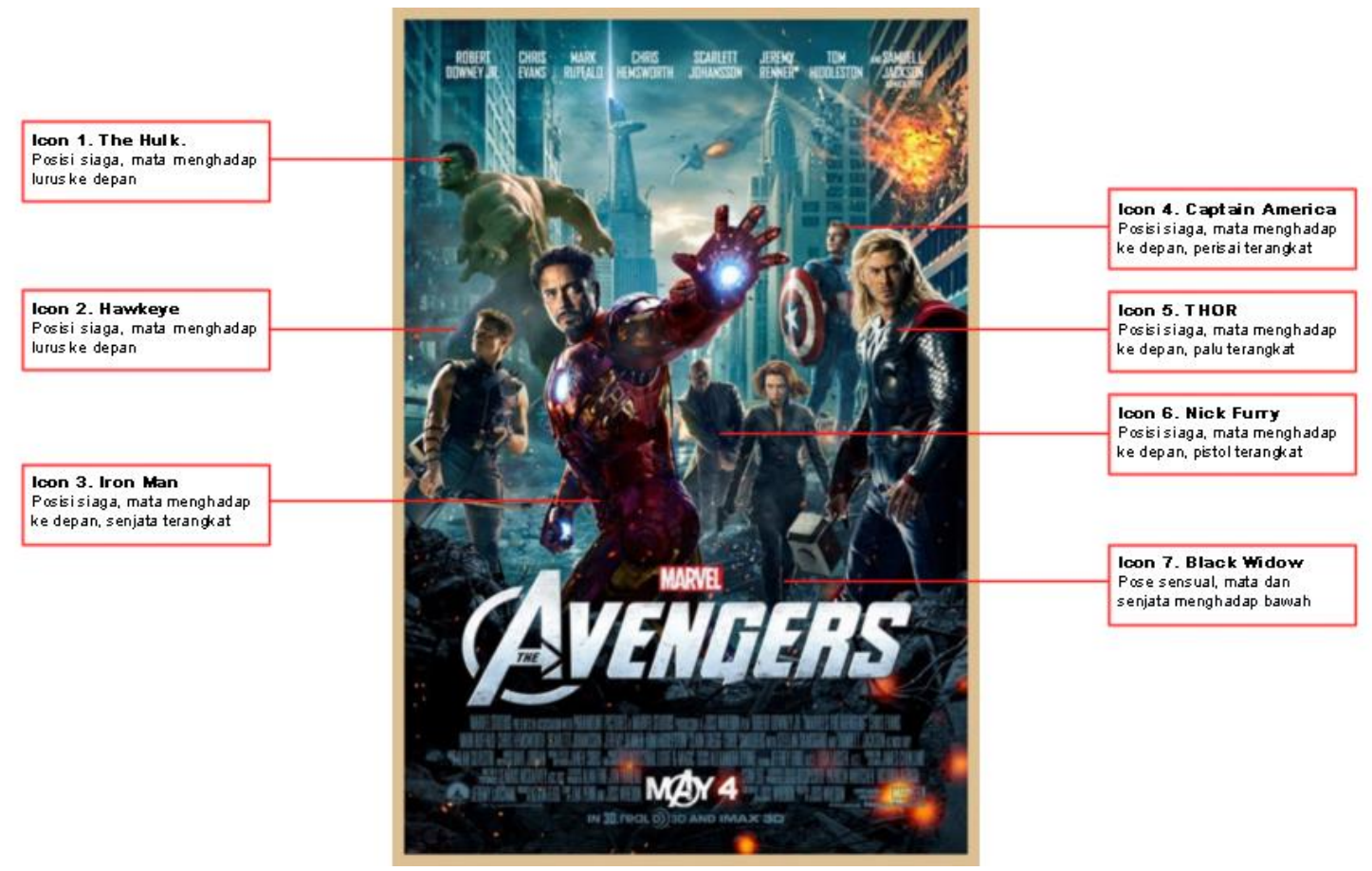

Gambar 5. Analisa ikon karakter pada Poster The Avengers

[Sumber: Olah data oleh peneliti]

Dekonstruksi total pada struktur peran dan visualisasi perempuan dalam film superhero baru terlihat jelas pada film dan serialisasi televisi yang dirilis sekitar tahun 2015. Berawal dari serial televisi "Supergirl" yang ditayangkan oleh CBS. Supergirl merupakan serial televisi yang mengisahkan superhero perempuan diantara padatnya dominasi superhero laki-laki yang memenuhi media masa sejak kebangkitan ulang genre superhero di awal tahun 2000-an.

Serial Supergirl secara tegas menangkat tema-tema feminisme dan kesetaraan gender. Bahkan dikisahkan bahwa musuh terbesar Supergirl adalah ekspektasi peran dan identitas gender tradisional Amerika. Seperti umum ditemui pada masyarakat urban masa kini, masyarakat fiktif dalam kisah Supergirl juga masih terjebak dalam konstruk patriakis tradisional Amerika. Bagi masyarakat yang masih menganut nilai-nilai tradisional, sosok seorang superhero idealnya adalah pria yang mewakili segala nilai maskulinitas. Akibat terjebak dalam penilaian gender tradisional, mereka tidak dapat menerima bahwa superhero perempuan juga kuat dan mampu melindungi yang lemah. Sepanjang serial, Supergirl harus berjuang mendekonstruksi cara pandang masyarakat sebelum mereka akhirnya mengakui bahwa perempuan mampu menjadi superhero yang setara dengan laki-laki. 
Perjuangan dan representasi karakter Supergirl tergambarkan dengan jelas dalam visualisasi poster filmnya. Poster ini merupakan dekonstruksi dari tradisi visual poster superhero yang nyaris tidak pernah menempatkan karakter perempuan sebagai fokus utama (Gambar 5), atau memberi karakter perempuan pose yang tidak heroik dan menonjolkan lekuk tubuh semata (Gambar 4) dan (Gambar 5).

Dalam poster ini ikon Supergirl ditampilkan lewat foto pose heroik dengan satu tangan terkepal di depan dan terbang di udara. Tidak hanya pose dan porsi dalam poster, dari sisi kostum pun pakaian Supergirl terdesain dengan baik dan tidak mengobyektifikasi tubuh pemakainya.

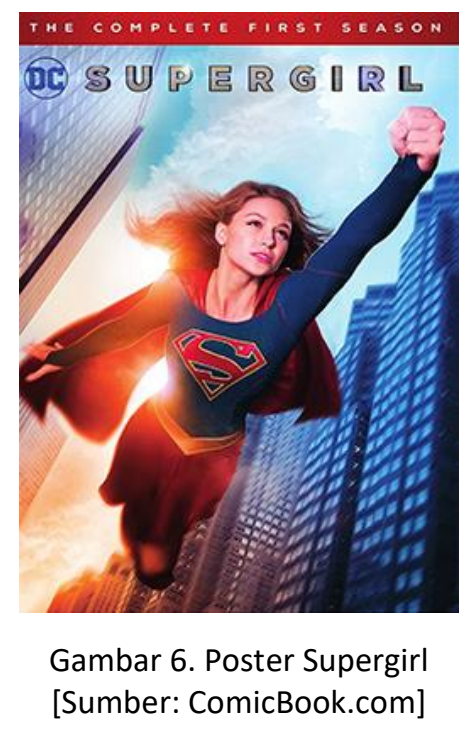

Supergirl yang kini memasuki penayangan musim kelima-nya, menjadi angin segar yang membawa pergeseran paradigma di Hollywood. Kesuksesan Supergirl, mendorong pihak DC-Comics melalui WB Studio untuk memproduseri dan merilis film Wonder Woman di tahun 2017.

Film Wonder Woman yang dengan jelas membalik ekspektasi peran dan identitas gender yang selama ini dianut oleh Hollywood. Dimulai dari proses di balik layar, film ini disutradarai oleh sutradara perempuan Patty Jenkins. Hal ini merupakan sesuatu yang baru di Hollywood, karena pada umumnya film superhero atau film-film aksi Hollywood yang terkenal berbudget besar tidak disutradarai oleh perempuan. Data dari pusat studi untuk Perempuan dalam Televisi dan Film di San Diego State University, dari 250 judul film terlaris Amerika pada tahun 2016, hanya tujuh persen diantaranya disutradarai oleh perempuan.

Dari sisi pemilihan pemeran, film Wonder Woman juga tidak menggambarkan perempuan sebagai sosok inferior. Wonder Woman diceritakan tumbuh besar di Themyscira, pulau fiksional yang dihuni kaum Amazon, pejuang perempuan yang berlatih keras dan mengasah fisik tiap hari. Untuk menunjang premis tersebut, para 
prajurit Amazon dalam film ini diperankan oleh atlit-atlit profesional, misalnya juara tinju perempuan Ann J. Wolfe, ahli Wushu Samantha Jo dan juara Crossfit Brooke Ence.

Selain representasi fisik yang tidak mengikuti konstruk gender tradisional, cerita Wonder Woman juga menunjukkan bahwa perempuan mampu merangkul sifat-sifat maskulin sekaligus feminin. Wonder Woman adalah sosok kuat dan tangguh,namun sepanjang film ia juga digambarkan penuh empati dan lemah lembut. Film Wonder Woman mendobrak stereotip Hollywood bahwa superhero identik dengan sifat-sifat maskulin semata. Maskulinitas dan feminitas adalah sifat-sifat yang tidak berkaitan dengan jenis kelamin.

Dekonstruksi yang terjadi di balik layar dan pada cerita film Wonder Woman, terefleksikan dengan jelas dari visualisasi posternya pada Gambar 7 di bawah. Dalam poster ini ikon Wonder Woman, digambarkan berada di depan, tengah memimpin dan melindungi para karakter di belakangnya termasuk laki-laki. Ikon Wonder Woman juga tidak berpose sensual yang menonjolkan lekuk tubuh, sebaliknya Wonder Woman memandang lurus ke depan, dan siap bertarung.

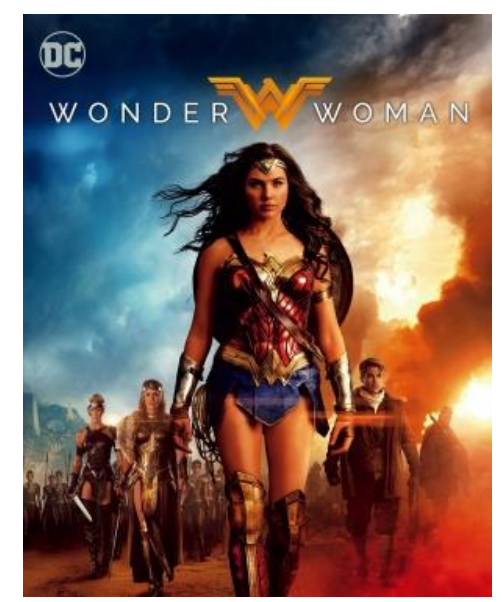

Gambar 7. Poster Wonder Woman

[Sumber: Amazon.co.uk]

Representasi positif karakter superhero perempuan pada poster film Wonder Woman tidak lepas dari proses dekonstruksi dalam berbagai aspek yang terjadi di balik layar, selain pada aspek jalan cerita dan representasi fisik karakter seperti yang telah dibahas sebelumnya. Dekonstruksi juga terjadi pada aspek visual, khususnya desain kostum Wonder Woman. Sebagaimana diketahui, tokoh Wonder Woman pertama kali tampil di media komik pada tahun 1950 an, lalu kemudian dalam serialisasi TV pada tahun 1970 an hingga akhirnya membintangi dalam film-nya sendiri di tahun 2017. 


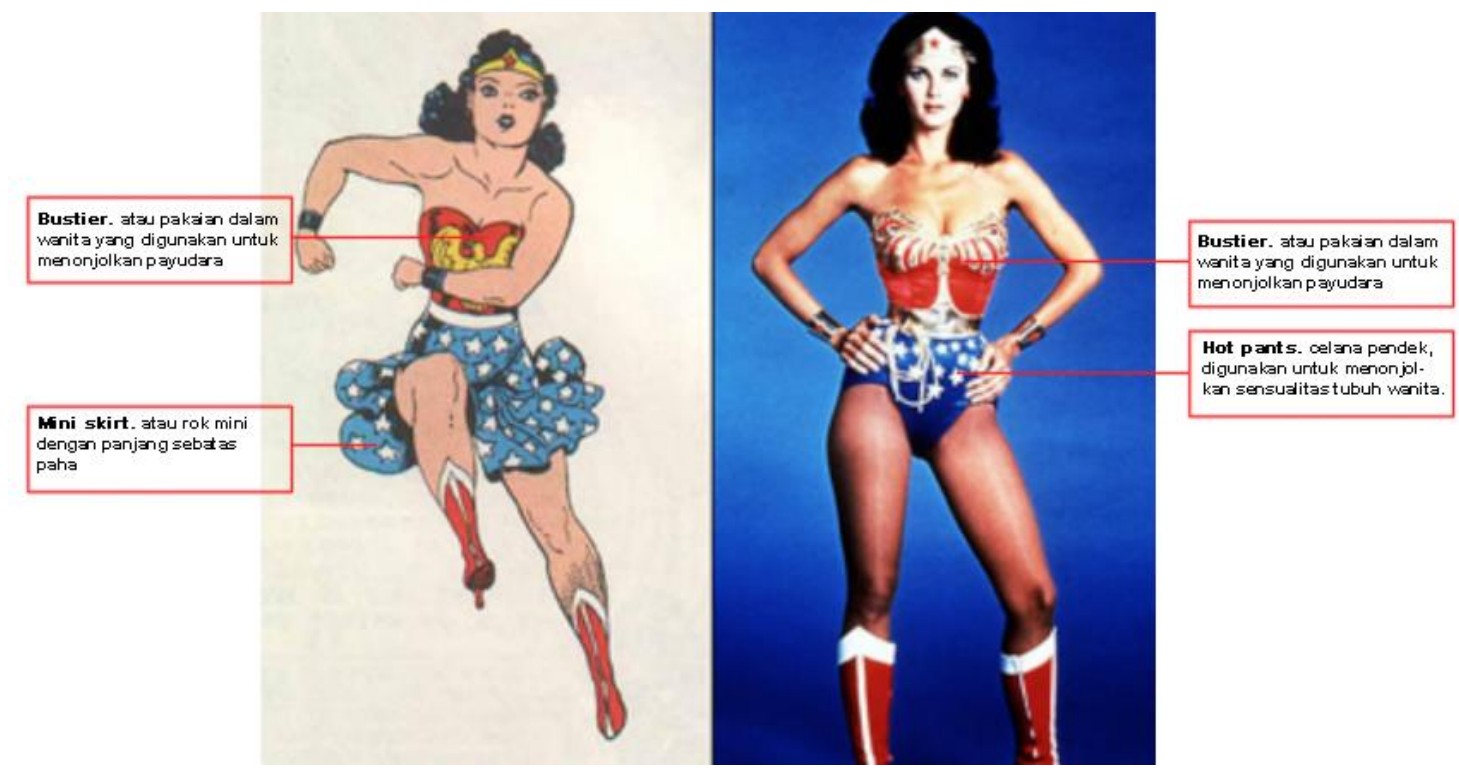

Gambar 8. Analisa kostum Wonder Woman 1960 dan 1970

[Sumber: Olah data oleh peneliti]

Dari gambar di atas dapat diamati bahwa visualisasi Kostum Wonder Woman pada film tahun 2017 telah jauh berkembang dibandingkan penampilan perdananya di tahun 1960 dan 1970. Kostum awal Wonder Woman terbuat dari bahan kain yang sangat menonjolkan lekuk tubuh. Bagian atas kostum Wonder Woman menyerupai bustier atau pakaian wanita yang memberikan ilusi pinggang yang ramping dan digunakan untuk menonjolkan bagian payudara dan lekuk pinggang wanita. Bagian bawahnya berupa mini skirt atau rok wanita yang umumnya hanya menutupi sebatas paha dan terbuat dari bahan kain. Pada kostum yang ditampilkan di serialisasi Wonder Woman, desain bustier dipertahankan namun rok mini digantikan dengan busana hot pants, atau celana yang sangat pendek umum digunakan untuk menonjolkan sensualitas tubuh wanita. Kostum ini tidak mencitrakan kesan tangguh juga tidak memberikan praktikalitas untuk bertarung, bahkan cenderung menjadikan Wonder Woman sebagai objek seksual.

Sedangkan visualisasi terbaru kostum Wonder Woman dirancang oleh desainer Australia Michael Wilkinson. Michael terinspirasi oleh pakaian perang Yunani dan Gladiator Romawi kuno yang mementingkan perlindungan dan mobilitas dalam pertempuran. Desain Rok mini dan hot-pants telah digantikan oleh Pteruges atau semacam lapisan kulit tebal berlapis yang digunakan untuk melindungi bagian bawah pinggang. Pteruges yang biasa digunakan oleh prajurit Yunani dan Romawi kuno untuk membantu mobilitas saat bertarung. Bustier merah Wonder Woman kini telah digantikan dengan Cuirass berwarna sama. Cuirass atau pelindung dada adalah lempengan baja yang dibentuk menyerupai torso dan biasa digunakan oleh prajurit Yunani dan Romawi kuno untuk melindungi tubuh mereka. Tidak hanya kostum, dalam film, Wonder Woman juga digambarkan mampu bertarung menggunakan perisai dan pedang seperti prajurit Yunani dan Romawi yang dijadikan inspirasi untuk desain visual karakter tersebut. 


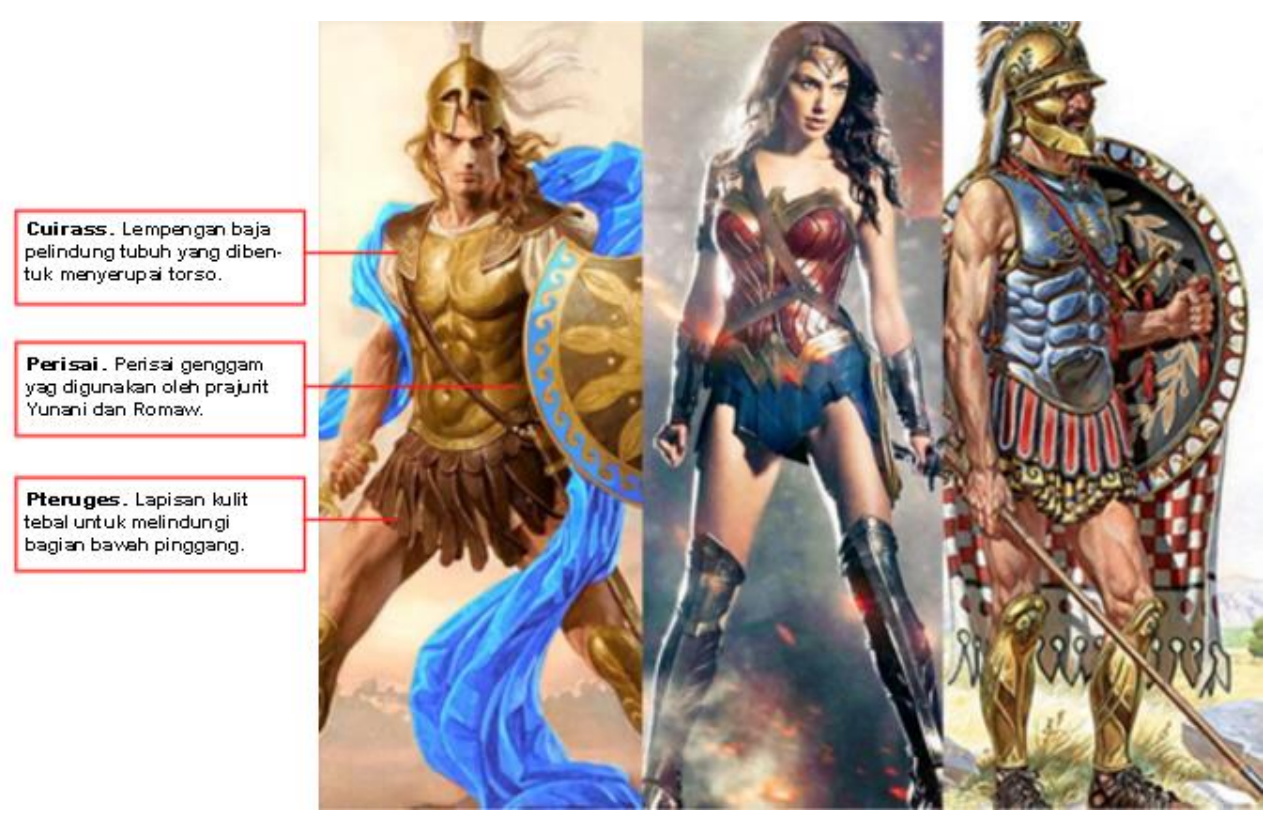

Gambar 9. Baju prajurit Yunani dan Romawi dan kostum Wonder Woman 2017

[Sumber: Olah data oleh peneliti]

Hal ini menunjukkan bahwa kostum Wonder Woman dirancang dengan tujuan untuk praktikalitas saat bertempur (d'Estries, 2018) Kostum Wonder Woman tidak menjadikan karakter ini sebagai obyek seksualitas, seperti yang teramati pada visualisasi kostum di poster film Catwoman (Gambar 3) atau kostum Black Widow pada film The Avengers (Gambar 8). Sehingga, tidak dapat dipungkiri bahwa desain kostum karakter Superhero turut andil dalam representasi positif karakter perempuan yang kemudian tercermin dalam poster film Wonder Woman.

Maka dari itu, dapat ditarik sebuah kesimpulan bahwa untuk menghasilkan desain poster film yang mampu merepresentasikan karakter perempuan dengan baik, maka dekonstruksi representasi karakter perempuan harus dimulai dari balik layar, diantaranya dari materi film (cerita dan karakterisasi), representasi fisik (casting/ pemilihan aktris), serta visualisasi (desain kostum).

\subsection{Implikasi dalam Bidang Desain Komunikasi Visual}

Dalam bidang desain komunikasi visual khususnya sinematografi, fenomena dekonstruksi konstruk patriakis Hollywood ini merupakan sebuah perubahan yang perlu disikapi dengan pikiran terbuka oleh para pelaku industri kreatif khususnya industri sinema. Walaupun pada kenyataannya di dunia nyata banyak ditemui pria atau perempuan yang mampu merangkul aspek-aspek diluar konstruk gender yang ditetapkan masyarakat untuk mereka. Namun masyarakat pada umumnya memang masih sangat memegang teguh nilai-nilai patriakis yang menentukan peran-peran gender pria dan perempuan berdasar seks semata, sehingga nilai-nilai inilah yang akhirnya tampil dalam film.

Perempuan dalam film pada umumnya juga digambarkan mengikuti konstruk gender tradisional lemah lembut dan tidak berdaya, bahkan tidak jarang menjadi obyek 
seksualitas. Genre superhero memang tergolong sesuatu yang baru jika dibandingkan dengan sejarah industri film Hollywood, namun munculnya serangkaian film superhero produksi Marvel dan DC sejak tahun 2000-an turut mendorong terjadinya dekonstruksi pada representasi karakter perempuan di Hollywood.

Representasi karakter perempuan yang kuat dalam film dapat menciptakan model positif untuk masyarakat khususnya bagi perempuan muda. Sebaiknya, saat karakter perempuan ditampilkan hanya sebatas mengkonfirmasi konstruk gender tradisional sebagai sosok yang lemah atau sebagai obyek romantis dan seksual, hal ini dapat akan menjadi model negatif bagi perempuan muda. Para pelaku industri film khususnya yang bergerak dalam produksi film, memiliki pengaruh dalam membentuk pandangan masyarakat terhadap seks dan gender. Dengan merepresentasikan karakter perempuan dan pria tanpa terbelengu oleh konstruk gender tradisional, film dapat menjadi media perubahan yang mendekonstruksi nilai-nilai patriakis kuno yang sudah tidak sesuai perkembangan jaman.

Seperti yang telah dibahas dalam sub point di atas, untuk benar-benar mendekonstruksi peran gender tradisional perempuan dalam sebuah film yang tercermin pada desain posternya, maka dekonstruksi harus dilakukan melalui beberapa aspek sekaligus yaitu:

1. Aspek kreatif penokohan, yaitu penulisan tokoh perempuan yang berkarakter, memiliki tujuan hidup, dan tidak semata berada dalam sebuah cerita untuk mendapatkan afeksi karakter pria atau hanya untuk diselamatkan oleh pahlawan super

2. Aspek visualisasi dan representasi fisik karakter perempuan sesuai dengan peran yang diharapkan dalam cerita.

3. Aspek desain kostum. Untuk karakter superhero perempuan, desain kostum dirancang berdasarkan fungsi dan praktikalitas serta tidak semata untuk menjadikan karakter sebagai obyek seksualitas

Visualisasi materi promosi film merupakan refleksi akhir dari keseluruhan proses dekonstruksi tersebut. Poster film superhero mewakili apa yang termuat di dalam filmnya. Film yang memiliki pesan feminitas kuat yang terkandung dalam cerita dan penokohannya serta didukung dengan visualisasi karakter maupun desain yang tidak mengobyektifikasi tubuh perempuan, akan terepresentasikan secara positif pula pada desain posternya.

\section{KESIMPULAN}

Penyajian tanda-tanda visual pada poster film superhero produksi Amerika Serikat bebrapa tahun terakhir ini mengalami perubahan. Ilustrasi dan penempatan tokoh superhero perempuan pada poster film superhero Amerika Serikat tidak lagi sevagai obyek tetapi sudah tampil menjadi subjek dan sejajar dengan superhero laki-laki.

Ilustrasi poster film superhero Amerika Serikat yang dulu cenderung menekankan pada sosok perempuan sebagai objek yang perlu dilindungi kini dalam beberapa poster telah melihatkan kesetaraan dengan superhero laki-laki. Tampilan ekspresi figur perempuan 
yang semula sebagai daya tarik seksual atau digambarkan lemah kini telah menunjukan kekuatannya.
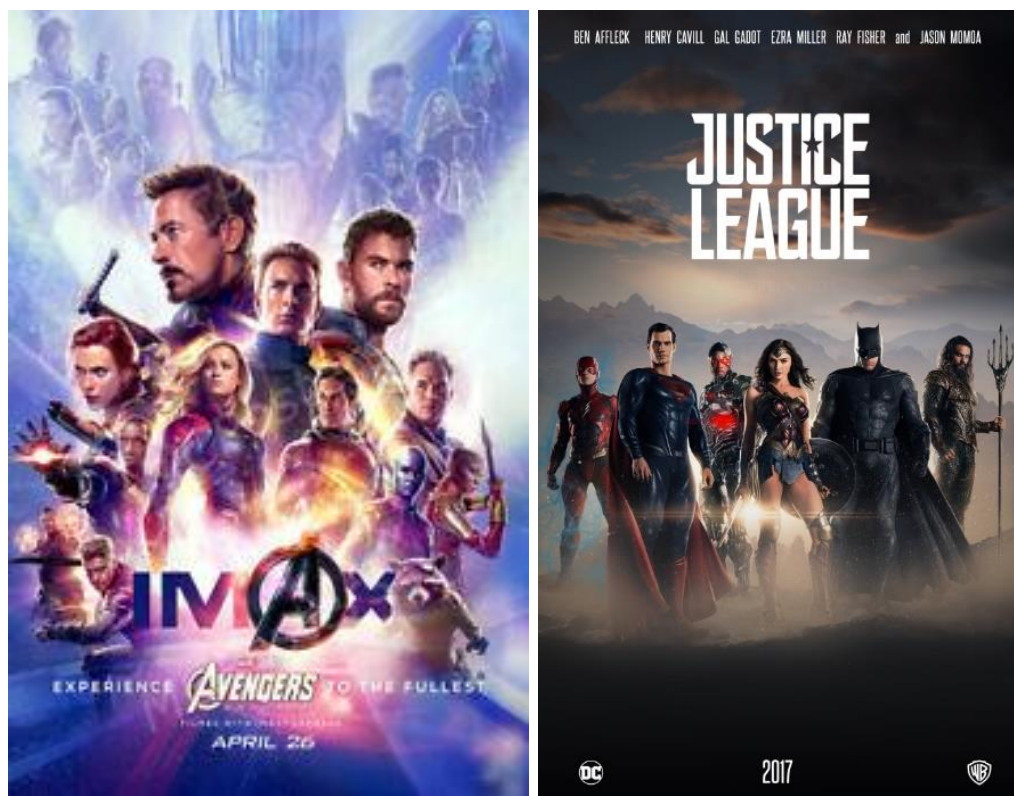

Gambar 10. Poster film Avengers End Game (2019) dan Justice League (2017) [Sumber: imdb.com]

Hal ini dapat dilihat pada poster film Avangers Endgame dan Justice League pada Gambar 1 di atas. Kedua poster ini memperlihatkan kesetaraan gender antara karakter superhero perempuan dan laki-laki. Pada poster Avengers End Game misalnya, terdapat 13 ikon karakter Superhero yang empat di antaranya adalah Superhero perempuan. Fokus poster diberikan cukup berimbang untuk setiap ikon karakter Superhero sesuai peran mereka dalam cerita, bahkan ikon karakter Captain Marvel ditempatkan pada di sisi depan poster, dengan setiap karakter diberikan bahasa tubuh heroik baik pria maupun wanita. Poster ini menunjukkan adanya perbedaan nyata dibandingkan dengan poster The Avengers 2012 (Gambar 5). Sama halnya dengan poster film Justice League yang menempatkan ikon karakter Wonder Woman di depan ikon karaker superhero pria lainnya.

Hasil pengamatan pada poster-poster film ini menunjukkan bahwa ada pergeseran representasi karakter perempuan ditampilkan dalam poster film pahlawan super Hollywood. Dekonstruksi representasi perempuan dalam poster film merupakan sebuah cerminan nyata dari upaya dekonstruksi tradisi patriarkis, dan merupakan hasil akhir dari dekonstruksi secara total yang dimulai dari proses produksi film di balik layar mulai dari penokohan (1), visualisasi dan representasi fisik (2), visualisasi kostum (3)

Sebagai film pahlawan superhero yang menjadi tontonan masyarakat dan panutan anakanak maka dekonstruksi peran gender tradisional perempuan dalam sebuah film harus dilakukan, terutama dalam aspek visualisasi materi promosi film. 
Penggambaran karakter perempuan dalam poster film superhero kini mulai sesuai dengan realita sosial konsep perempuan di dunia nyata. Karakter-karakter perempuan yang ditampilkan dalam film-film superhero terbaru adalah refleksi dari karakter ideal perempuan modern. Representasi karakter perempuan mengalami diseminasi sebagai akibat dari pasar yang merasa jenuh terhadap konsep patriarkis dan juga karena munculnya gerakan feminisme yang mengkritisi representasi perempuan sebagai objek seksual dalam poster-poster film. Hal tersebut mendorong para pelaku industri film untuk tidak lagi menempatkan perempuan sebagai obyek, tetapi sebagai subjek.

Representasi positif perempuan dalam poster film bergenre superhero baru telah terlihat sejak pertengahan dekade lalu. Perempuan dalam film-film Superhero mulai ditampilkan karakternya dan direpresentasikan dalam poster menggunakan ikon-ikon yang mencerminkan kepribadian kuat, ketangguhan, dan keberanian. Perempuan tidak lagi direpresentasikan dengan ikon-ikon yang memposisikan perempuan sebagai karakter yang lemah atau dalam kostum dan pose yang menonjolkan lekuk tubuh.

\section{DAFTAR PUSTAKA}

Barker, Chris. (2011). Cultural Studies: Theory and Practice (fourth). SAGE Publications Ltd.

d'Estries, Michael. (2018). The evolution of Wonder Woman's iconic costume. Fromthegrapevine. https://www.fromthegrapevine.com/arts/wonderwoman-costume-history-gal-gadot

Dutt, R. (2014). Behind the curtain: women's representations in contemporary Hollywood.

http://www.Ise.ac.uk/media@lse/research/mediaWorkingPapers/MScDissert ationSeries/2013/msc/112-Dutt.pdf

Dwijowijoto, R. N. (2008). Gender dan administrasi publik (1st ed.). Pustaka Pelajar.

Early, Francis H.. (2001). Staking Her Claim: Buffy the Vampire Slayer as Transgressive Woman Warrior. The Journal of Popular Culture, 35(3), 11-27. https://doi.org/10.1111/j.0022-3840.2001.3503_11.x

Fakih, Mansour. (2016). Analisis Gender dan Transformasi Sosial (15th ed.). INSISTPress. https://insistpress.com/katalog/analisis-gender-dan-transformasi-sosial/

Fischer, Sabrina. (2010). Powerful or Pretty: A Content Analysis of Gender Images in Children's Animated Films [Auburn University]. https://etd.auburn.edu/bitstream/handle/10415/2065/ThesisSabrinaFischer. pdf;jsessionid=D2B74A2F2DD65BCEFC5FB17041B83F34?sequence $=2$

Gerard, M. P. (2018). Black Widow: Female Representation in the Marvel Cinematic Universe. Polymath: An Interdisciplinary Arts and Sciences Journal, 8(2), 27-53. https://ojcs.siue.edu/ojs/index.php/polymath/article/view/3314

Heldman, C., Frankel, L. L., \& Holmes, J. (2016). "Hot, Black Leather, Whip": The (De)evolution of Female Protagonists in Action Cinema. Sage Journals, 2(2). https://doi.org/10.1177/2374623815627789

Mau, Alfred Ena. (2016). Kesetaraan Gender : "Peran Antara Laki-laki dan Perempuan Yang Seimbang." Bengkelappek.Org. http://www.bengkelappek.org/opini/174 -kesetaraan-gender-peran-antara-laki-laki-dan-perempuan-yang- 
seimbang.html

McKay, B. D. (2013). The use of digital photography in systematics. Biological Journal of the Linnean Society, 110(1), 1-13. https://doi.org/10.1111/bij.12086

Moore, Henrietta L. (1994). A Passion for Difference: Essays in Anthropology and Gender. Indiana University Press.

Parker, Holt N. (2011). Toward A Definition Of Popular Culture. History and Theory, 50(2), 147-170. https://doi.org/0.11111/j.1468-2303.2011.00574.x

Pasquine, F. (2013). Gender Inequality in Film. NYFA. https://www.nyfa.edu/film-schoolblog/gender-inequality-in-film/

Pennell, H., \& Behm-Morawitz, E. (2015). The empowering (super) heroine? The effects of sexualized female characters in superhero films on women. Sex Roles: $A$ Journal of Research, 72(5), 211-220. https://doi.org/https://doi.org/10.1007/s11199-015-0455-3

Stabile, C. (2009). "Sweetheart, This Ain't Gender Studies": Sexism and Superheroes. Communication and Critical/Cultural Studies, 6(1), 86-92. https://doi.org/10.1080/14791420802663686 